\title{
EFEKTIVITAS KEBIJAKAN PEMERINTAH MENGENAI PEMBELAJARAN DARING DI KALANGAN MAHASISWA
}

\author{
Purnamaningsih ${ }^{1}$ \\ E-mail: ekapurnama@unud.ac.id \\ Wismayanti ${ }^{2}$ \\ E-mail: wiwin.fisip@unud.ac.id
}

Fakultas Ilmu Sosial dan Ilmu Politik Universitas Udayana

\begin{abstract}
The Covid-19 pandemic in Indonesia has had a huge impact on various sectors of people's lives, especially in the world of education. One of the policies made by the government in overcoming educational problems in the midst of a pandemic, the government took a policy to implement distance learning or online as an effort to overcome education in the midst of a pandemic. Distance learning is a process of learning activities that are not carried out in one place at the same time but carried out in different places through online. This study aims to see the effectiveness of online learning among students. This study uses descriptive research with qualitative methods where this method describes the problem under study clearly by reviewing and describing the existing data in detail and systematically. Data collection techniques were carried out by indirect and direct interviews. Sources of data used are secondary and primary data. This study uses indirect interviews in the form of a questionnaire with 100 respondents by giving 5 questions. The results of this study indicate that $56 \%$ of students responded that they were quite satisfied with online learning. The media used in online learning $90 \%$ said using webex. The material presented in the learning process was quite well received by students. The obstacles faced by students in online learning showed that $48 \%$ did not understand the material presented.

And the results of the latest research show $64 \%$ of respondents said the online learning process is quite effective.
\end{abstract}

Keywords: Effectiveness of government policies, online learning, Covid-19 pandemic

\section{PENDAHULUAN}

Pendidikan adalah kegiatan yang dilakukan secara sadar dan terencana untuk mengembangkan potensi diri dalam memiliki kekuatan pengendalian diri, akhlak, keagamaan, kecerdasan, kepribadian serta keterampilan yang diperlukan dirinya, 
masyarakat, bangsa dan negara untuk mendapatkan hal tersebut dapat dilakukan melalui proses pembelajaran. Namun saat ini seluruh negara yang ada di dunia sedang menghadapi wabah virus covid-19 dan WHO telah menetapkan sebagai kedaruratan kesehatan masyarakat yang membuat keresahan di masyarakat. Hal ini juga berdampak bagi Indonesia, kemunculan virus COVID-19 di Indonesia saat ini berdampak bagi seluruh bidang seperti sosial, ekonomi, pariwisata dan pendidikan. Penyebaran Covid-19 yang ada di Indonesia semakin hari semakin meningkat menanggulangi penyebaran virus ini pemerintah telah melakukan berbagai upaya mulai dari larang untuk berkerumun, PSBB, pembatasan sosial (social distancing) dan menjaga jarak fisik (physical distancing), memakai masker dan selalu cuci tangan.

Adanya virus Covid-19 yang ada di Indonesia menjadi tantangan terbesar bagi pendidikan Indonesia dimana adanya larangan berkerumun. Untuk mengatasi masalah pendidikan pada tanggal 24 Maret 2020 Menteri Pendidikan dan Kebudayaan Republik Indonesia menerbitkan Surat Edaran Nomor 4 Tahun 2020 tentang Pelaksanaan Kebijakan Pendidikan Dalam Masa Darurat Penyebaran Coronavirus Disease (COVID19), dalam Surat Edaran menjelaskan bahwa kegiata pembelajran dilakukan di rumah melaui daring. Kebijakan pembelajaran daring juga didukung dengan terbitnya Surat Edaran Nomor 3 Tahun 2020 pada Satuan Pendidikan dan Nomor 36962/MPK.A/HK/2020 tentang Pelaksanaan Pendidikan dalam Masa Darurat Coronavirus Disease (COVID19). Segala kegiatan yang melibatkan sekumpulan orang dibatasi bersekolah, bekerja, beribadah dan lain sebagainya, pemerintah menghimbau kegiatan tersebut dilakukan dari rumah untuk menekan angka pasien yang terpapar COVID-19. Adanya kebijakan tersebut tentu membuat lembaga pendidikan harus melakukan inovasi dalam proses pembelajaran. Salah satunya dengan melakukan pembelajran jarak jauh melalui daring. Hal ini dilakukakan dengan tujuan agar proses pembelajaran dapat tercapai secara utuh walaupun tidak dilakukan secara tatap muka.

Pembelajaran jarak jauh adalah suatu proses kegaitan pembelajaran yang tidak dilakukan disuatu tempat yang bersamaan melainkan dilaksanakan ditempat yang berbeda melalui daring dengan pemanfaatan teknologi komunikasi, informasi dan media lainnya dalam menunjang kegiatan pembelajaran. Pembelajran jarak jauh atau PJJ juga bisa disebut 
dengan pembelajaran daring. Melalui pembelajaran daring ini, interaksi antara mahasiswa dengan dosen akan mudah dilakukan karena adanya kemajuan teknologi seperti adanya aplikasi yang dapat menunjang pelaksanaan pembelajaran daring. Dapat dikatakan juga dengan adanya kemajuan teknologi ini menyediakan kemudahan dalam mengakses materi yang diberikan dan memberikan pembelajaran. Pembelajaran online atau daring menjadi tantangan baru pagi pekerja pendidik yang menuntu mereka menjadi tenaga pengajar yang cakap dalam penggunaan teknologi digital dalam proses pembelajaran online sehingga dapat meningkatkan kreativitas tenaga pengajar. Dalam melakukan pembelajaran online, bukan saja tenaga pangajar yang memiliki peran dalam proses pembelajaran melainkan semua pihak yang terlibat dalam proses pembelajaran online harus memililiki kesiapan dalam pelaksanaanya seperti koneksi jaringan internet yang memadai dan fasilitas yang mendukung proses pembelajaran online sehingga proses pembelajaran dapat berjalan dengan efisien dan efektif.

Sayangnya pada awal proses pembelajaran online ditemukan beberapa kendala dalam pelaksananya yang belum optimal seperi adanya Sumber Daya Manusia yang masih pasif dan awam dalam penggunaan teknologi, adanya kendala jaringan internet dan fasilitas internet yang belum memadai. Selain itu adanya pembelajaran daring ini membuat para dosen atau tenaga pengajar tidak dapat mengawasi para siswnya dalam proses pembelajaran karena adanya jarak dan posisi yang berbeda. Berdasarkan pemaparan diatas peneliti ingin mengambil judul "Efektivitas Kebijakan Pemerintah Mengenai Pembelajaran Daring Di Tengah Pandemi Covid-19”. Penelitian ini untuk mengetahui sejauhmana kebijakan pemerintahan dalam sektor pendidikan telah berjalan dengan baik dan efektif. Permasalahan yang ingin penulis bahas yaitu bagaimana efektivitas kebijakan pemerintah mengenai pembelajaran daring ditengah pandemi Covid-19. Dan penelitian ini bertujuan untuk meninjau sejauh mana efektivitas pemerintah mengenai pembelajaran daring ditengah pandemi Covid-19.

\section{TINJAUAN TEORITIS}




\section{Kebijakan Publik}

Secara konseptual kebijakan publik dapat dilihat dari Kamus Administrasi Publik Chandler dan Pleno seperti dikutip dalam Pasolong (2007:38-39) mengatakan bahwa kebijakan publik adalah pemanfaatan yang strategis terhadap sumber - sumber daya yang ada untuk memecahkan masalah publik dalam pemerintah.

Thomas R. Dye seperti dikutip dalam Pasolong (2007:39) bahwa kebijakan publik adalah "apapun yang dipilih pemerintah untuk dilakukan atau tidak dilakukan", Dye mengatakan bahwa bila pemerintah memilih untuk melakukan sesuatu maka harus ada tujuannya (objektifnya) dan kebijakan publik itu meliputi semua tindakan pemerintah, jadi bukan semata - mata merupakan pernyataan keinginan pemerintah atau pejanat pemerintah saja.

Jadi dapat disimpulkan bahwa kebijakan publik dibuat berdasarkan suatu permasalahan yang dapat diselesaikan dengan membahas setiap persoalan kemudian disusun menjadi sebuah agenda kebijakan untuk mencapai tujuan dan sasaran tertentu yang telah ditetapkan. Maksud tujuan dan sasaran kebijakan publik dibuat adalah untuk memecahkan masalah publik yang tumbuh dan berkembang di masyarakat. Namun, tidak semua masalah publik dapat dijadikan sebuah kebijakan publik, karena masalah tersebut memiliki banyak macam, variasi dan intensitasnya. Hanya masalah publik yang dapat menggerakan orang banyak untuk ikut memikirkan dan mencari solusi yang bisa menghasilkan sebuah kebijakan publik. Dalam pandangan Ripley dalam Taufiqurokhman (2014), tahapan kebijakan publik yaitu Tahap Penyusunan Agenda, Tahap Formulasi dan Legitimasi Kebijakan, Tahap Implementasi Kebijakan Publik, Tahap Evaluasi Kebijakan.

\section{Teori Efektivitas}

Efektivitas berasal dari kata efektif yang mengandung pengertian dicapainya keberhasilan dalam mencapai tujuan yang telah ditetapkan. Efektivitas selalu terkait dengan hubungan antara hasil yang diharapkan dengan hasil yang telah dicapai. Efektivitas dapat dilihat dari berbagai sudut pandang (view point) dan dapat dinilai dengan berbagai cara dan mempunyai kaitan yang erat dengan efisiensi. Adapun pendapat para ahli mengenai definisi efektivitas yaitu: 
1. Menurut pendapat Mahmudi (2005:92) mendefinisikan efektivitas, sebagai berikut: "Efektivitas merupakan hubungan antara output dengan tujuan, semakin besar kontribusi (sumbangan) output terhadap pencapaian tujuan, maka semakin efektif organisasi, program atau kegiatan". Efektivitas berfokus pada outcome (hasil), program, atau kegiatan yang dinilai efektif apabila output yang dihasilkan dapat memenuhi tujuan yang diharapkan atau dikatakan spending wisely. Efektivitas menggambarkan seluruh siklus input, proses dan output yang mengacu pada hasil guna daripada suatu organisasi, program atau kegiatan yang menyatakan sejauhmana tujuan (kualitas, kuantitas, dan waktu) telah dicapai, serta ukuran berhasil tidaknya suatu organisasi mencapai tujuannya dan mencapai targettargetnya. Hal ini berarti, bahwa pengertian efektivitas yang dipentingkan adalah semata-mata hasil atau tujuan yang dikehendaki.

2. Menurut pendapat Drucker yang dikutip Moenir (2006:166) yang mendefinisikan efektivitas, sebagai berikut: "Effectivennes, on the other hand, is the ability to choose appropriate objectives. An effective manager is one who selects the right things to get done". (Efektivitas, pada sisi lain, menjadi kemampuan untuk memilih sasaran hasil sesuai. Seorang manajer efektif adalah satu yang memilih kebenaran untuk melaksanakan)".

3. Menurut pendapat Zahnd (2006:200) mendefinisikan efektivitas dan efisiensi, sebagai berikut: "Efektivitas yaitu berfokus pada akibatnya, pengaruhnya atau efeknya, sedangkan efisiensi berarti tepat atau sesuai untuk mengerjakan sesuatu dengan tidak membuang-buang waktu, tenaga dan biaya”. Berdasarkan penjelasan di atas, bahwa efektivitas lebih memfokuskan pada akibat atau pengaruh sedangkan efisiensi menekankan pada ketepatan mengenai sumber daya, yaitu mencakup anggaran, waktu, tenaga, alat dan cara supaya dalam pelaksanaannya tepat waktu.

4. Menurut Kurniawan (2005:109) mendefinisikan efektivitas, sebagai berikut: "Efektivitas adalah kemampuan melaksanakan tugas, fungsi (operasi kegiatan program atau misi) daripada suatu organisasi atau sejenisnya yang tidak adanya tekanan atau ketegangan diantara pelaksanaannya". 
Berdasarkan pendapat para ahli diatas dapat diketahui bahwa efektivitas merupakan suatu konsep yang sangat penting karena mampu memberikan gambaran mengenai keberhasilan suatu organisasi dalam mencapai sasarannya atau dapat dikatakan bahwa efektivitas merupakan tingkat ketercapaiannya tujuan dari aktivasi- aktivasi yang telah dilaksanakan dibandingkan dengan target yang telah ditetapkan sebelumnya.

\section{Teori Pembelajaran}

Pembelajaran adalah seperangkat tindakan yang dirancang untuk mendukung proses belajar siswa, dengan memperhitungkan kejadian-kejadian ekstrim yang berperanan terhadap rangkaian kejadian-kejadian intern yang berlangsung dialami siswa (Winkel 1991). Sementara Gagne (1985), mendefinisikan pembelajaran sebagai peraturan peristiwa secara seksama dengan maksud agar terjadi belajar dan membuatnya berhasil guna. Dalam pengertian lainnya, Winkel (1991) mendefinisikan pembelajaran sebagai pengaturan dan penciptaan kondisi-kondisi ekstem sedemikian rupa, sehingga menunjang proses belajar siswa dan tidak menghambatnya.

Pengertian pembelajaran yang dikemukakan oleh Miarso (1993), menyakan bahwa pembelajaran adalah usaha pendidikan yang dilaksanakan secara sengaja, dengan tujuan yang telah ditetapkan terlebih dahulu sebelum proses dilaksanakan, serta pelaksanaannya terkendali. Dari beberapa pengertian pembelajaran yang telah dikemukakan, maka dapat disimpulkan beberapa ciri pembelajaran sebagai berikut:

1. Merupakan upaya sadar dan disengaja

2. Pembelajaran harus membuat siswa belajar

3. Tujuan harus ditetapkan terlebih dahulu sebelum proses dilaksanakan.

4. Pelaksanaannya terkendali, baik isinya, waktu, proses mapun hasilnya.

\section{METODELOGI PENELITIAN}

Didalam penelitian ini, menggunakan penelitian deskriptif dengan metode kualitatif dimana metode ini menggambarkan tentang masalah yang diteliti secara jelas dengan menelaah dan menguraikan data yang ada secara rinci dan sistematis. Teknik pengumpulan data pun dilaksanakan dengan wawancara tidak langsung dan langsung. Sumber data 
yangdigunakan yaitu data sekunder dan primer. Data sekunder digunakan untuk mendukung informasi data asli yang telah diperoleh, yaitu dari bahan pustaka, dokumen, penelitian terdahulu, buku, terbitan berkala. Selain menggunakan data sekunder penelitian ini juga menggunakan data primer yakini dengan melaksanakan wawancara langsung dan tidak langsung kepada sejumlah mahasiswa.

\section{HASIL DAN PEMBAHASAN}

Masifnya kasus penyebaran Covid-19 di Indonesia mengharuskan pemerintah mengambil langkah cepat dalam menanggulangi penyebaran kasus Covid-19, salah satunya adalah dengan meniadakan pembelajaran secara tatap muka di dalam dunia pendidikan Indonesia. Pembelajaran yang biasanya dilaksanakan secara konvensional melalui tatap muka kini digantikan dengan metode pembelajaran jarak jauh melalui pemanfaatan teknologi, yang dikenal dengan istilah pembelajaran via daring. Pembelajaran via daring ini dilakukan dengan menggunakan aplikasi pembelajaran online seperti ZOOM, Cisco Webex, G-Meet, dan lain sebagainya. Sejalan dengan pelaksanaanya banyak pro dan kontra yang dirasakan oleh peserta didik mulai tingkat dasar hingga perguruan tinggi. Sisi positifnya selain dapat membantu dalam memutus mata rantai penularan Covid-19, pembelajaran via daring dapat membiasakan peserta didik terhadap penggunaan dan pemanfaatan teknologi sehingga mengurangi buta teknologi di masyarakat mengingat persaingan global yang tengah dihadapi pada dunia industry. Pembelajaran via daring juga dianggap lebih memiliki variasi metode pembelajaran, ketimbang peserta didik hanya berada di dalam kelas, kini peserta didik lebih fleksibel belajar dari rumah dan tentunya peserta didik memiliki banyak waktu di rumah bersama keluarga dan mengembangkan diri di luar dari kegiatan sekolah. Tetapi, pada pelaksanaanya sejauh ini pembelajaran via daring dianggap sangat membebani peserta didik dengan banyaknya tugas yang diberikan pada setiap mata pelajaran, sehingga waktu sebagian besar digunakan untuk terus menerus mengerjakan tugas sekolah, kemudian kendala jaringan sinyal internet, ketidaksiapan guru atau tenaga pendidik dalam memberi kelas, bahkan bebrapa dari peserta didik tidak memiliki sarana dan prasarana pembelajaran daring, seperti handphone, laptop, WIFI, 
internet, dan sebaginya yang disebabkan oleh banyak faktor mulai dari ekonomi hingga kondisi geografis tempat tinggal peserta didik.

Dampak Pandemi Covid-19 pada dunia pendidikan mengharuskan adanya kerjasama seluruh pihak dan elemen masyarakat bersama-sama mewujudkan pembelajaran daring yang efektif. Untuk menciptakan efektivitas pembelajaran secara daring, diperlukan adanya inovasi dan kreatifitas pendidik dalam proses pembelajaran dalam proses penyampaian materi kepada peserta didik agar output yang didapat oleh peserta didik dalam memahami materi pelajaran lebih maksimal dan peserta didik tidak menjadi cepat bosan terhadap metode pembelajaran daring ini. Untuk dapat mengetahui efektivitas pembelajaran daring, peneliti mengajukan beberapa pertanyaan melalui kuesioner yang sangat relevan untuk diisi secara jujur oleh responden yang bersedia mengisi kuesioner ini. Responden dalam kuesioner ini adalah para mahasiswa perguruan tinggi yang merasakan langsung sistem pembelajaran daring. Berikut ini beberapa pertanyaan yang diajukan kepada responden:

\section{Bagaimana tanggapan anda sebagai mahasiswa yang telah melaksanakan pembelajaran daring selama satu tahun?}

Pertanyaan ini diajukan bertujuan untuk mengetahui tingkat kepuasan mahasiswa selama pembelajaran daring yang telah terlaksana kurang lebih satu tahun belakangan. Kepuasan mahasiswa terhadap pembelajaran daring perlu diiukur agar kedepannya sistem pembelajaran daring dapat dibenahi apakah pelaksanaan perkuliahan daring efektif atau justru membuat mahasiswa kurang puas dalam menjalani perkuliahan. Kemudian tingkat kepuasan mahasiswa juga tentunya mempengaruhi kualitas pembelajaran itu sendiri. Berikut hasil survei terhadap kepuasan mahasiswa dalam pembelajaran daring:
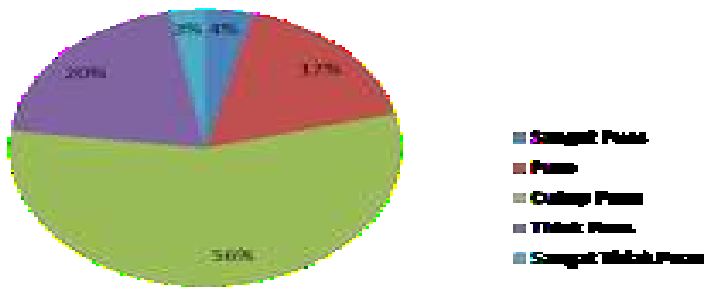
Berdasarkan gambar 1 tentang Hasil Kepuasan Mahasiswa Terhadap Pembelajaran Daring dengan jumlah responden sebanyak 100 orang mengatakan bahwa terdapat sebanyak 56\% mahasiswa merasa cukup puas dengan pembelajaran secara daring dan hanya ada 3\% mahasiswa saja yang merasa sangat tidak puas terhadap pembelajaran daring dan terdapat 17\% mahasiswa yang merasa puas terhadap proses pembelajaran daring. Sisanya $4 \%$ merasa sangat puas dan $20 \%$ merasa tidak puas. Berdasarkan data tersebut dapat disimpulkan bahwa pembelajaran daring cukup disukai oleh sebagian besar mahasiswa.

\section{Media apa yang anda gunakan selama pembelajaran daring?}

Pertanyaan ini diberikan untuk mengetahui media atau jenis aplikasi apa yang paling banyak digunakan selama proses pembelajaran daring. Berbagai macam aplikasi pembelajaran daring tersedia pada market online yang dapat diunduh dengan mudah secara gratis. Penentuan aplikasi yang digunakan menggambarkan efektivitas pembelajaran. Tentunya aplikasi pembelajaran yang efektif ialah aplikasi yang dapat memfasilitasi pembelajaran dua arah secara langsung seperti ZOOMatau WEBEX. Sedangkan terdapat beberapa kelas atau mata kuliah yang lebih memilih pembelajaran daring via email dan

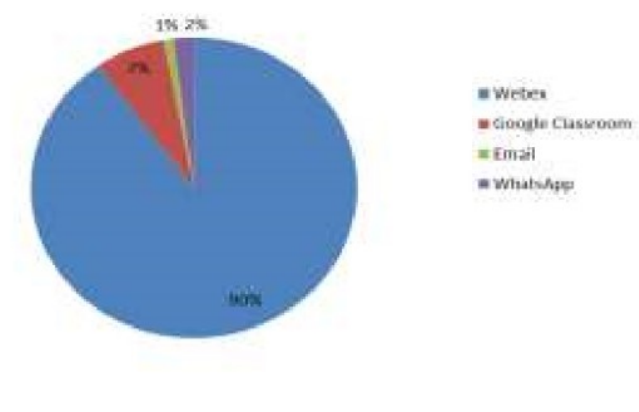

whatsapp yang termasuk pada aplikasi pembelajaran daring satu arah. Berikut hasil survei terhadap aplikasi yang digunakan dalam pembelajaran daring:

Gambar 2. Media Daring Yang Digunakan Dalam Pembelajaran Online 
Berdasarkan gambar 2 tentang Media Daring Yang Digunakan Dalam Pembelajaran Online mengatakan bahwa aplikasi webex berada diurutan pertama dengan jumlah $90 \%$ dari total 100 responden. Hal ini mengartikan bahwa pembelajaran daring dilakukan dengan menggunakan aplikasi yang dapat mewadahi komunikasi dua arah antara pendidik dengan peserta didik, antara dosen dengan mahasiswanya. Akan tetapi masih terdapat 7\% responden menggunakan Google Classroom, 2\% menggunakan Whasapp, dan 1\% menggunakan email dalam proses pembelajaran daring. Padahal ketiga aplikasi (Google Classroom, Whatsapp, dan Email) tersebut tidak dapat melakukan pembelajaran secara face to face. Artinya, masih terdapat dosen ataupun mahasiswa yang belum melek teknologi atau terhalang kendala lainnya seperti jaringan sinyal, ketersediaan sarana pembelajaran misalnya handphone atau laptop.

\section{Apakah materi yang disampaikan dosen telah tersampaikan?}

Pertanyaan ini diajukan untuk mengetahui seberapa besar materi yang disampaikan dosen mampu diterima dengan baik oleh mahasiswa. Pertanyaan ini akan mampu menjawab tingkat keberhasilan pembelajaran daring yang dilakukan selama masa pandemi Covid-19. Berikut adalah hasil survei terhadap materi yang disampaikan oleh dosen kepada para mahasiswa.

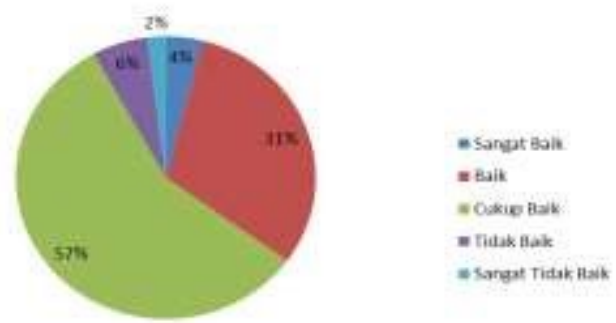

Gambar 3. Hasil Penyampaian Materi Ajar Dalam Permbelajaran Online

Berdasarkan gambar 3 tentang Hasil Penyampaian Materi Ajar Dalam Pembelajaran Online menunjukan bahwa 57\% responden menjawab cukup baik, $31 \%$ responden menjawab baik, $6 \%$ responden menjawab tidak baik, lalu $4 \%$ responden menjawab sangat baik, dan sisanya menjawab sangat tidak baik hanya 2\% saja. Hal ini membuktikan bahwa selama pembelajaran daring, materi yang disampaikan oleh dosen cukup tersampaikan 
dengan baik dapat terserap secara keseluruhan oleh mahasiswa. Dalam kurun waktu kurang lebih satu tahun mahasiswa mulai terbiasa dengan proses pembeljaran yang baru, yaitu pembelajaran melalui daring. Akan tetapi perlu diperhatikan pula masih terdapat 6\% jawaban responden yang mengatakan tidak baik. Hal ini bisa terjadi karena materi disampaikan secara terus menerus ataupun ada beberapa sub materi yang tidak tersampaikan. Hal ini wajar terjadi karena umumnya setiap mata kuliah terdiri dari 15 kali tatap muka. Dengan pembelajaran daring, beberapa dosen memadatkan materi ajar sehingga hanya 3 sampai 5 kali melakukan pembelajaran daring bahkan tidak sedikit dosen yang memangkas materinya sehingga tidak semua materi tersampaikan kepada mahasiswa.

\section{Apa kendala yang anda hadapi ketika proses pembelajaran daring?}

Pertanyaan ini diajukan untuk mengetahui faktor apa saja yang menjadi kendala sehingga menyebabkan tidak efektifnya pembelajaran daring. Beberapa faktor tersebut diantaranya sinyal internet, keterbatasan kuota, keterbatasan teknologi, dan pemahaman materi yang disampaikan kurang jelas. Pertanyaan ini nantinya akan mapu menjawab kendala apa yang dominan dihadapi selama proses pembelajaran daring. Berikut adalah hasil survei tentang kendala dalam proses pembelajaran daring:

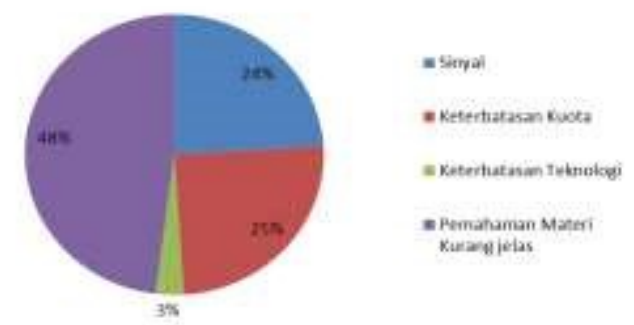

Gambar 4. Kendala Dalam Pembelajaran Daring

Berdasarkan gambar 4 tentang Kendala Dalam Pembelajaran Daring menunjukan bahwa 48\% responden merasa kurang jelas dalam memahami materi yang disampaikan, $25 \%$ responden mengeluhkan terhadap adanya keterbatasan kuota. Hal ini dirasa wajar mengingat dalam satu hari umumnya terdapat dua hingga tiga mata kuliah yang kurang lebih menghabiskan waktu 1,5 sampai 2 jam pelajaran, hal ini tentunya menghabiskan 
banyak kuota internet, 24\% responden menjawab tidak ada sinyal, 3\% responden menjawab gagap teknologi dalam arti tidak mengerti menggunakan beragam aplikasi daring. Kurang jelasnya materi pembelajaran yang dapat ditangkap oleh mahasiswa bisa jadi karena disebabkan oleh tingkat kejenuhan yang tinggi, mengingat pembelajaran daring yang tidak dapat bertatap muka secara langsung, adanya gangguan koneksi internet yang mengakibatkan materi tidak terdengar jelas oleh mahasiswa, dan rasa bosan yang karena seharian mengikuti pembelajaran tanpa tatap muka secara langsung. Hal ini adalah hal yang wajar terjadi pada mahasiswa bahkan tidak hanya mahasiswanya saja yang merasa bosan atau jenuh, dosen pun merasakan hal sama. Untuk mengantisipasi rasa jenuh tersebut mayoritas dosen memadatkan materinya atau bahkan hanya melaksanakan perkuliahan sebulan sekali bergantian antara webex, tugas, dan lain-lain.

\section{Apakah proses pembelajaran daring efektif untuk proses belajar mengajar?}

Pertanyaan ini diajukan untuk mengetahui bagaimana perasaan peserta didik dala hal ini mahasiswa mengenai pembelajaran di masa pandemi Covid-19. Apakah bagi mereka pembelajaran daring selama ini berjalan secara efektif atau tidak, pilihannya adalah efektif, cukup efektif, dan tidak efektif. Pertanyaan ini diajukan agar peneliti dapat menyimpulkan hasil temuannya di lapangan terkait efektivitas pembelajaran daring di masa pandemi Covid-19. Jika sebagian besar responden memilih efektif artinya pembelajaran daring ini disenangi dan dianggap efektif bagi peserta didik untuk diterapkan dalam proses belajar mengajar di sekolah dan/atau perguruan tinggi, namun sebaliknya jika responden sebagaian besar menjawab tidak efektif, artinya pembelajaran daring yang selama ini telah dilakukakn tidak berjalan dengan efektif dan bukan sebagai metode pembelajaran yang diharapkan oleh peserta didik. Berikut adalah hasil survei terhadap mahasiswa mengenai perasaan mereka di dalam melaksanakan pembelajaran daring.

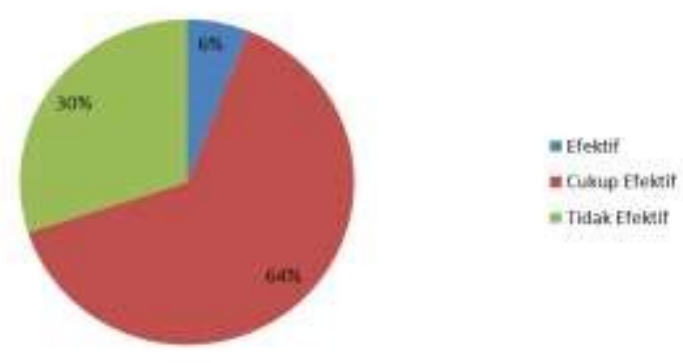




\section{Gambar 5. Pendapat Responden Terhadap Keefektifan Proses Belajar Mengajar Pembelajaran Secara Daring}

Berdasarkan gambar 5 tentang Pendapat Responden Terhadap Keefektifan Proses Belajar Mengajar Pembelajaran Secara Daring menunjukan hasil 64\% responden mengatakan pembelajaran secara daring cukup efektif terlaksanakan. 30\% responden mengatakan pembelajaran daring tidak efektif dilaksanakan dan sebanyak $6 \%$ responden yang mengatakan pembelajaran daring efektif dilaksanakan. Hal ini membuktikan bahwa meski sebagian besar mahasiswa merasa cukup efektif, pembelajaran secara daring ini perlu dievaluasi secara berkala agar terlaksana benar-benar efektif.

Dari hasil temuan di lapangan peneliti menemukan permasalahan dan kendala yang sangat dominan dihadapi dalam proses pembelajaran secara daring di masa Pandemi Covid19 yaitu, sulitnya mahasiswa dalam mencerna dan memahami materi yang disampaikan. Hal ini dapat disebabkan oleh beberapa faktor. Pertama, karena jenuhnya mahasiswa dalam mengikuti pembelajaran. Dalam sehari mahasiswa dapat mengikuti kurang lebih dua hingga 3 mata kuliah dengan rata-rata 2 jam per mata kuliah,hal ini menjadikan mahasiswa merasa lelah, bosan, dan mudah terinterupsi dengan hal-hal lain disekitanya, sehingga mahasiswa melewati materi yang disampaikan. Kedua, adanya kendala jaringan seringkali ditengahtengah pembahasan materi suara dan gambar yang ditampilkan tidak jelas yang disebabkan oleh koneksi internet yang buruk, hal ini tidak hanya dialamai oleh mahasiswa, tetapi dosen pengajar juga turut mengalami permasalah yang sama ketika menyampaikan materi pembelajaranya kepada mahasiswa. Ketiga, ialah metode pembelajaran yang monoton dan tidak kreatif, gaya dan pembawaan dosen dalam mengajar sangat mempengaruhi antusiasme mahasiswa dalam mengikuti pelajaran dan menerima materi yang disampaikan dengan gaya yang selalu sama dapat membuat mahasiswa bosan dan mengabaikan materi yang disampikan oleh dosen ketika proses pembelajaran tengah berlangsung. Permasalahan lainnya yang dihadapi dalam pemebelajaran daring ialah adanya keterbatasan kuota. Banyaknya kuota yang harus dikeluarkan ketika mengikuti kelas daring, menjadi beban 
tersediri bagi mahasiswa. Mengingat pada masa pandemi kondisi ekonomi juga ikut terpuruk, sehingga beberapa mahasiswa merasa kesulitan dalam membeli kuota internet. Meskipun begitu, secara keseluruhan proses pembelajaran secara daring ini dirasa telah cukup terlaksanakan dengan baik dan efektif, meski masih terdapat beberapa kendala teknis yang terjadi pada setiap proses pembelajarannya, yang mana berdasarkan data sebanyak 64\% merasa pembelajaran daring terlaksana dengan cukup efektif. Meskipun begitu, pembelajaran secara daring masih perlu dievaluasi secara berkala pelaksanaannya agar nantinya pembelajaran secara daring ini benar benar terlaksana dengan maksimal dan dapat memudahkan peserta didik dalam memahami materi pembelajaran.

\section{KESIMPULAN}

Berdasarkan dari hasil temuan dan pembahasan dapat disimpulkan bahwa proses pembelajaran secara daring yang telah terlaksana kurang lebih setahun belakangan ini cukup terlaksana dengan efektif. Meskipun terdapat beberapa kendala yang dirasakan oleh mahasiswa misalnya seperti keterbatasan kuota internet mengingat kondisi ekonomi juga ikut terpuruk pasca pandemi Covid-19. Kendala lainnya ialah kemampuan mahasiswa dalam menangkap dan memahami materi pembelajaran yang diberikan oleh dosen dalam pembelajaran daring. Hal ini terjadi karena mahasiswa seringkali merasa jenuh dan bosan mengikuti kelas daring selama satu minggu. Dengan demikian pembelajaran daring dirasa lebih efektif bila hanya dilakukan sewaktu-waktu tidak terus menerus selama 1 semester. Dapat dibayangkan jika pembeljaran daring terus dilakukan tanpa diselingi dengan metode lain mengingat mata kuliah yang cukup banyak dengan jangka waktu yang lama pula mengharuskan mahasiswa terus berhadapan dengan layar handphone dan laptop mereka yang menyebabkan kejenuhan dan kebosanan yang cukup tinggi ditambah dnegan banyaknya tugas yang diberikan. Selain merasa jenuh hal ini juga dapat mengakibatkan mahasiswa tidak dapat mengasah skill, hobi atau kemampuan mereka di luar jam pelajaran kuliah. Untuk itu diperlukan adanya proses evaluasi dalam proses belajar mengajar di masa pandemi Covid-19. 


\section{DAFTAR PUSTAKA}

Dewantara, Aditnya \& Nurgiansah, 2021. Efektivitas Pembelajaran Daring di Masa Pandemi Covid.19 Bagi Mahasiswa Universitas PGRI Yogyakarta. Jurnal Basi Cedu Vol. 5 No. 1 Hal. 367-375. Tersedia di https://jbasic.org/index.php/basicedu/article/view/669

Latifah, 2021, Perubahan Tingkah Laku Siswa Melalui Komunikasi Antar Pribadi Guru Pendidikan Agama Islam, Al Kalam Vol. 7, No.2, Juli 2021.

Marliana Noor, 2021, Upaya Meningkatkan Hasil Belajar Bahasa Indonesia Pada Kompetensi Menentukan Kosa Kata Tentang Peristiwa Siang Dan Malam Dengan Menggunakan Model Pembelajaran Example Non-Example Pada Siswa Kelas I SDN Berangas 1 Kecamatan Alalak, Al Ulum Vol. 7, No.1,

YolandaSari, Mega Berlian, 2020. Efektivitas pembelajaran daring dalam pembelajaran bahasa Indonesia di kelas II A Mi unggulan Miftahul Huda tumang Cepogo Boyolali tahun pelajaran 2019-2020

http://erepository.perpus.iainsalatiga.ac.id/9550/ 